\title{
Impact of a coral disease outbreak on coral communities in St. Lucia: What and how much has been lost?
}

\author{
Maggy M. Nugues* \\ Environment Department, University of York, Heslington, York YO10 5DD, United Kingdom
}

\begin{abstract}
In July 1997, a coral disease called plague appeared on the coral reefs of St. Lucia, West Indies. A survey of 6 coral species on 3 reefs in March 1998 revealed an overall disease incidence of $11 \%$. Montastraea faveolata and Colpophyllia natans were the most affected species with $19 \%$ and $13 \%$ of colonies infected respectively. Disease frequency was independent of coral density and the distribution of the disease among $5 \times 5 \mathrm{~m}$ plots was not clumped, suggesting that proximity to affected colonies did not increase probability of infection. Among-colony size variation in disease incidence and tissue mortality indicates that small coral colonies are more likely to escape infections than large colonies, but once infection occurs, small colonies will experience faster colony mortality. This suggests that the effect of the disease on coral population structure will be greater total mortality in small colonies relative to large colonies, at least over short-time scales. At the most severely affected site, it was estimated in March 1998 that plague had killed 6.6\% of living coral during the preceding 8 months. Despite these losses being small compared to losses from other well-known disturbances on coral reefs, such as hurricanes, the disease selectively impacted 2 major reef frame builders. More than $90 \%$ of the estimated tissue loss was accounted for by Montastraea faveolata and Colpophyllia natans combined. In addition, infected colonies continued to lose living tissue from February 1998 to October 1998, with no new coral recruitment observed on the substrate opened up by the disease. Of the colonies infected in February 1998, 28 \% still showed signs of disease in October 1998. Over the long term, if losses are sustained at such rates, plague could cause complete mortality in large colonies and could progressively deplete two of the most important reef frame builders in some of the richest and most visited coral reefs of St. Lucia.
\end{abstract}

KEY WORDS: Coral disease $\cdot$ Caribbean $\cdot$ Mortality $\cdot$ Coral population structure

Resale or republication not permitted without written consent of the publisher

\section{INTRODUCTION}

One of the central issues of coral reef conservation is to determine the major factors contributing to the decline of reefs. Among them, coral diseases have been largely neglected. Although the first coral diseases were described in the early 1970s (Antonius 1973, 1977, Garrett \& Ducklow 1975), the first detailed quantitative studies of coral disease abundance and

\footnotetext{
${ }^{*}$ Present address: Netherlands Institute for Sea Research (NIOZ), PO Box 59, 1790 AB Den Burg, Texel, The Netherlands.E-mail: mnugues@nioz.nl
}

distribution were only conducted in the early 1990s on black band disease (Edmunds 1991, Kuta \& Richardson 1996). Meanwhile, most research has been focused on other forms of disturbance, such as over-fishing and declining water quality, which have been considered more threatening to coral reef health (Roberts 1993).

To date, evidence from descriptive reports and coring of reef deposits clearly point out the need to assess the role of coral diseases in reef decline. Over the last decade, reports of coral disease have increased dramatically and more virulent diseases, new to science, have been described (Peters 1993, 1996, Santavy \& Peters 1997, Goreau et al. 1998, Richardson 1998, Harvell 
et al. 1999). Coral diseases have been found to infect more species, at a greater frequency and over a wider area than previously thought (Coles 1994, Miller 1996, Bruckner \& Bruckner 1997, Richardson et al. 1998a). Further, from cores taken through reefs in Belize, we have recently learnt that the near extinction of acroporid corals by white band disease was an unprecedented event over a millennial scale, i.e. $>3800 \mathrm{yr}$ (Aronson \& Precht 1997). However, efforts to study the disease have been very limited compared to the extreme nature of its impact (Precht \& Aronson 1997).

In this paper, I document the impact of a coral disease outbreak on coral communities in St. Lucia, West Indies. The disease outbreak first appeared on the island in July 1997 and diseased corals remained present until the end of the study in October 1998. Signs of disease were similar to those reported in 1975 in the Florida Keys in Dustan (1977). Typically the disease initiated at the base of the colony, or at lesions in the middle of the colonies, and radiated outward leaving behind bare white skeleton. Diseased colonies exhibited a sharp boundary between coral tissue and exposed skeleton, with no apparent microbial biomass. However, in the case of St. Lucia, the disease affected a larger number of coral species.

To date, there are 2 etiologies associated with this disease: plague type I (Dustan 1977) and plague type II (Richardson et al. 1998a,b). The latter type has been attributed to a bacterium of the genus Sphingomonas (Richardson et al. 1998a). However, since the infection agent for plague type I has not yet been identified, plague type I and type II could conceivably be the same thing (Richardson et al. 1998b). In this study, no attempt was made to identify the microorganisms associated with the signs of disease. What was identified as plague was based on the presence of consistent plague-like signs. As such, it could be in fact a consortium of diseases caused by different pathogens or a more generally stressrelated reaction presenting similar symptoms (Santavy \& Peters 1997). Correctly speaking it should be referred as a 'potential disease state' (sensu Richardson 1998).

Epizootics of plague have been reported in the Florida Keys in the 1970s, 1980s and 1990s (Dustan 1977, Dustan \& Halas 1987, Richardson et al. 1998a) and in Puerto Rico in 1996 (Bruckner \& Bruckner 1997). The last 2 studies reported high colony mortality, high rates of tissue degradation and rapid disease spread over a wide range of coral species, and concluded that plague could have an important role in restructuring coral reef communities. Therefore, the specific objectives of this study were: (1) to quantify the abundance and distribution of diseased corals; (2) to predict the impact of the disease on coral population and community structure by determining among-species and among-colony size variation in disease incidence and tissue mortality; and (3) to quantify the loss in living coral cover approximately $8 \mathrm{mo}$ after the onset of the outbreak. I also present the results of the monitoring of 64 infected coral colonies from February to October 1998 to determine the short-term impact of the disease on infected colonies.

\section{MATERIALS AND METHODS}

Study sites. Surveys were undertaken on 3 fringing reefs near the town of Soufrière, located midway along the west coast of St. Lucia (Fig. 1). Anse Chastanet and Grand Caille reefs range in depth from $1 \mathrm{~m}$ to approximately $50 \mathrm{~m}$. Turtle reef begins at $10 \mathrm{~m}$ deep and extends to approximately $40 \mathrm{~m}$ deep. It is separated from Anse Chastanet reef by a $50 \mathrm{~m}$ wide sand channel. The 3 reefs are located in the most developed and important reef area of St. Lucia. Turtle reef and Anse Chastanet reef are situated in a sheltered bay. They lie within a marine reserve protected from fishing since 1992. Large increases in fish stocks occurred following protection from fishing and it is expected that these 2 reefs play an important role in restoring fish stocks (Roberts \& Hawkins 1997). Grand Caille reef is relatively exposed. It was designated as marine reserve in 1995 but was re-opened to fishing in 1997. It is an important tra-

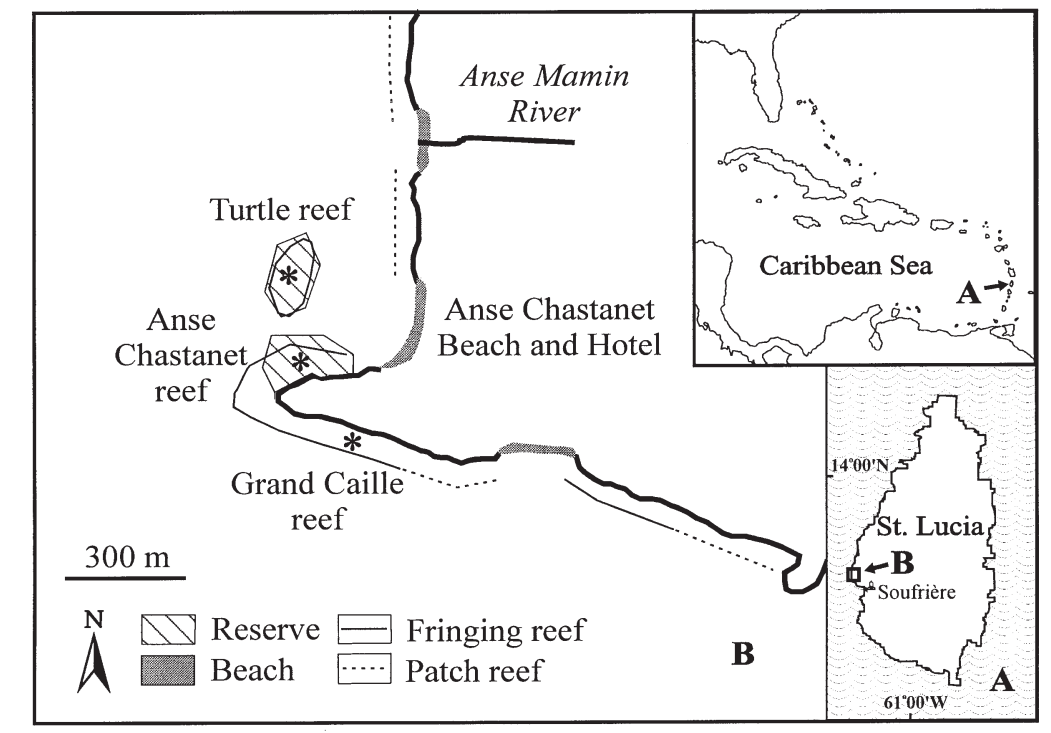

Fig. 1. Study sites (*) on St. Lucia. Hatched areas indicate Anse Chastanet Marine Reserve 
ditional fishing site, particularly for pot fishing (Fiona Gell pers. comm.). All 3 reefs are also extensively used by SCUBA divers and snorkellers. In 1997, they were characterised by high coral cover ( $>40 \%$, see Table 4 in 'Results'). At the time of the study, they were the most extensively affected by the disease. However, recent observations show the disease spreading to other reefs around Soufrière (Callum Roberts pers. comm.).

Abundance and distribution of diseased corals. Plague abundance was determined in randomly placed $5 \mathrm{~m}$ wide $\times 40 \mathrm{~m}$ long transects between 9 and $17 \mathrm{~m}$ depth in March 1998, approximately 8 mo after the first case of plague was seen on these reefs. Nine transects were sampled on each reef, making a total of 27 transects across the 3 reefs. Transects were oriented parallel to bathymetric contours. Transects crossing major sand channels or monospecific stands of Madracis mirabilis were not sampled.

Within each transect, the total number of uninfected and plague-infected colonies of Colpophyllia natans, Montastraea faveolata, $M$. annularis (following Weil \& Knowlton 1994), Diploria labyrinthiformis, D. strigosa and Stephanocoenia michelinii (total of 6 species) were counted. Preliminary surveys indicated that these species were the most commonly infected. However, it should be noted that sample sizes were limited for less common corals (D. strigosa and S. michelinii) for which conclusions may not be representative. The presence of diseased colonies of other species, and colonies affected by black band disease, were also recorded. A colony was defined as an autonomous mass of skeleton with living tissue. Thus, a colony divided by partial mortality or morphological characteristics (e.g. M. annularis) into separate patches of living tissue, but located on the same mass of skeleton, was considered to be 1 colony.

To determine whether the distribution of diseased corals was clumped, the number of diseased colonies present within the first $5 \mathrm{~m}$ of each transect (making a total of 27 plots, each measuring $5 \times 5 \mathrm{~m}$, across the 3 reefs) was counted. The frequency distribution of the number of plots with 0 to 5 or more infected colonies was then tested for goodness of fit to a Poisson distribution with a G-test as in Edmunds (1991). A Williams's correction factor was applied to avoid type I error (Sokal \& Rohlf 1995).

Influence of colony size on disease incidence and tissue mortality. Within the same transects as above, the maximal length $\left(d_{1}\right)$ and perpendicular width $\left(d_{2}\right)$ of all infected colonies were measured to the nearest $\mathrm{cm}$. The projected total surface area of each infected colony was subsequently calculated using the formula for an ellipse $\pi \times\left(d_{1} / 2\right) \times\left(d_{2} / 2\right)$. Tissue mortality, expressed as the percentage of colony surface area killed by the disease, was estimated visually and assigned in
$10 \%$ classes $(<10 \%, 10-19 \%, 20-29 \%$, and so on until 90-100\%). Dead sections of infected colonies were considered to have been killed by the disease when: (1) they were within 0 to $2 \mathrm{~mm}$ of the level of the living surface; (2) polyp skeletal structure was still clearly visible; and (3) surfaces were colonised by simple algal turf communities. However, since colonies were not monitored continuously, I cannot exclude the possibility that other causes (e.g. other coral diseases, bleaching) could have contributed to this mortality. Average tissue mortality for each colony was estimated by taking the midpoint of the tissue mortality class.

For the analysis, as sizes of uninfected colonies were not measured within the transects, the relationship between colony size and disease incidence could not be directly obtained. Therefore, I used data collected a month earlier (February 1998) where all colonies were measured regardless of their disease status. These data were collected at 2 reefs (Turtle reef and Grand Caille) for 2 species (Colpophyllia natans and Montastraea faveolata). The method of colony surface area estimation and the depth range were the same as used in the $5 \mathrm{~m}$ wide $\times 40 \mathrm{~m}$ long transects; however, circular areas of $10 \mathrm{~m}$ radius and $4 \mathrm{~m}$ wide $\times 10 \mathrm{~m}$ long transects were used in Turtle reef and Grand Caille respectively. The influence of colony size on disease incidence was compared using a 3-way ANOVA of the $\log _{\mathrm{e}}$ of colony surface area with species, disease status (infected colonies vs all colonies) and reef as independent variables. Since coral colony size distributions tend to be dominated by many small colonies and very few large colonies (Bak \& Meesters 1998), the log transformation was applied to colony surface area for all analyses of variance and colony size classes were expressed on logarithmic scales in the figures. Data were tested for normality and heterogeneity of variance prior to all analyses.

To assess the influence of colony size on tissue mortality, all infected colonies recorded in the 27 transects were pooled and species were compared with an analysis of covariance (ANCOVA) on tissue mortality with the $\log _{\mathrm{e}}$ of colony surface area as covariate. Using this analysis, species could be compared while variation in colony surface area among species was taken into account. Critical values for significance testing were adjusted using Bonferroni procedures to avoid type I error. Only species for which data were available for at least 6 infected colonies were included in this analysis (total of 9 species). The assumption of homogeneity of slopes between colony surface area and tissue mortality was checked prior to analysis.

Loss in living coral cover after 8 months of plague outbreak. The surface area of living coral killed by the disease was calculated for each transect and an averaged value per $100 \mathrm{~m}^{2}$ of reef area was calculated for 
each site. Since the total coral cover could not be estimated from the transect data, I used data on percent live coral cover collected at the start of the outbreak in July 1997 (Roberts et al. 1997). These data were collected at the same sites and approximately the same depth (13 to $16 \mathrm{~m}$ ). At each reef, a minimum of twelve $1 \mathrm{~m}^{2}$ quadrats were sampled randomly and the percentage of massive and branching corals were visually estimated within each quadrat. The surface area of living coral killed by the disease estimated in March 1998 was then expressed as a percentage of the live coral cover present in July 1997. However, this should be considered as a rough estimate due to possible biases associated with expressing the area of living coral killed by the disease within $9 \times 200 \mathrm{~m}^{2}$ transects as percent of living coral cover within $12 \times 1 \mathrm{~m}^{2}$ quadrats.

Short-term impact of plague on infected coral colonies. To investigate the short-term impact of plague on infected colonies, 32 Colpophyllia natans and 32 Montastraea faveolata infected colonies with living tissue were randomly selected and tagged in February 1998. Of these, 46 colonies were located at Turtle reef and 18 at Anse Chastanet reef, and were split equally between both species. On each tagged colony, 2 masonry nails were fixed less than $50 \mathrm{~cm}$ apart nearby the active disease band. Photographs of the entire colony and close-up photographs that included the 2 nails (approximately $60 \times 40 \mathrm{~cm}$ in size) were taken of all tagged colonies in February 1998 and repeated 8 mo later in October 1998.

Photographic slides were later projected, and the percentage of coral tissue killed by the disease was visually estimated from each whole-colony photograph using the same criteria and percentage classes as those described earlier. Notes were made of whether signs of plague were still present on colonies in October 1998. Close-up photographs were projected onto sheets of paper, and by comparing the photographs from February and October 1998, the progression of the disease front could be measured to the nearest $\mathrm{cm}$ using the 2 nails and other permanent natural features (e.g. tube worms) as reference points. Three coral colonies lost living tissue beyond the boundary of the photograph or the colony. These were excluded from the calculations. Additionally, the percentage of macroalgae (all fleshy algae $>1 \mathrm{~cm}$ in height) covering the areas killed by the disease was visually estimated from each close-up photograph taken in October 1998. These areas were also checked for the presence of new coral colonies.

Changes in tissue mortality over the $8 \mathrm{mo}$ period were tested by repeated measures ANOVA with species and reef as between-factor variables and time (February vs October 1998) as within-factor variable. All ANOVA and ANCOVA tests were done using the general linear model procedure in SPSS 10.0.

\section{RESULTS}

\section{General observations}

Typical examples of corals infected by plague are shown in Fig. 2. The disease frequently started at the base of the colony (Fig. 2A), but it also originated from lesions elsewhere on the colony (Fig. 2B). Other coral competitors such as algae, polychaetes and sponges were often interacting with the colony at the point of
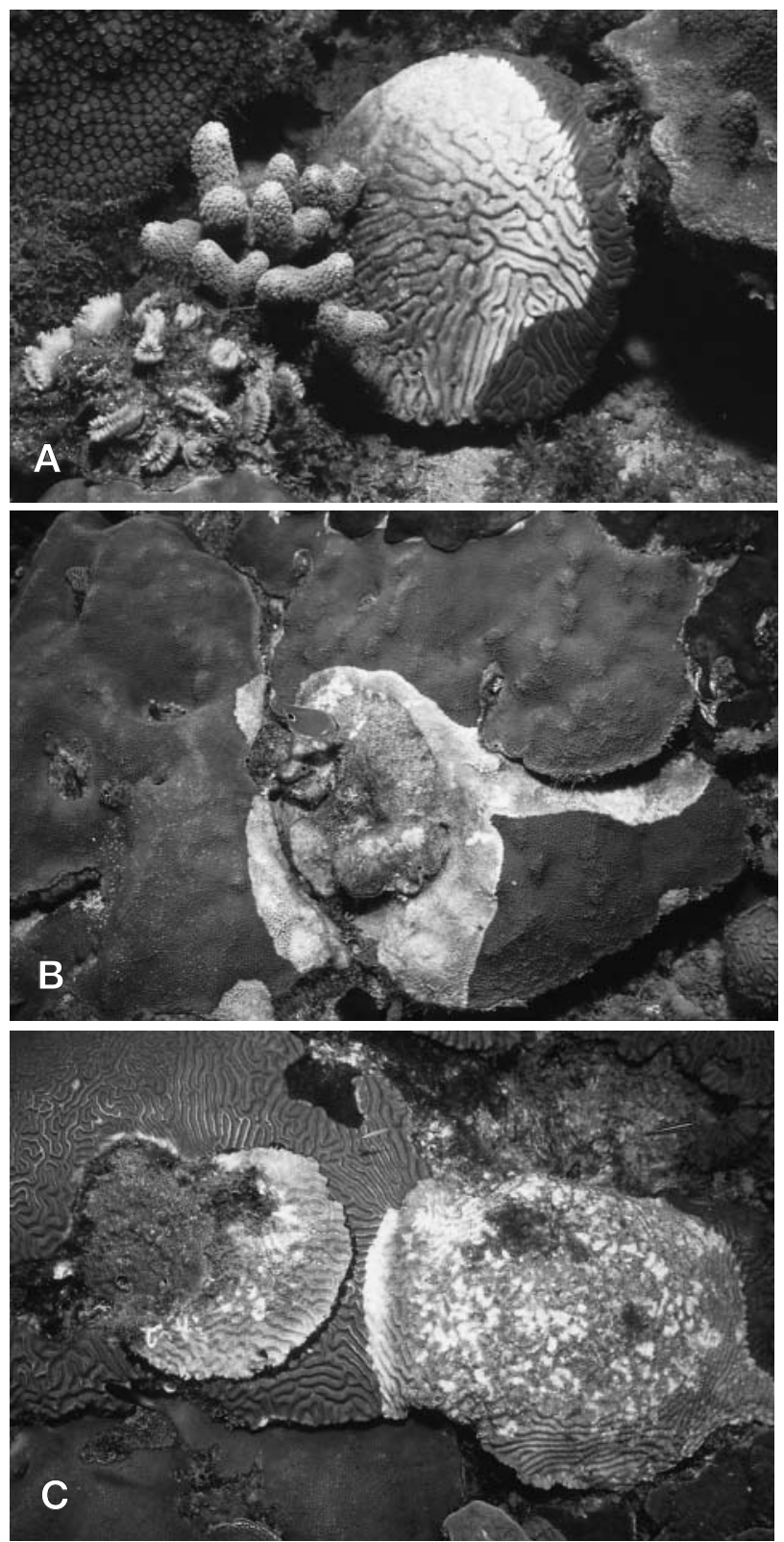

Fig. 2. In situ photographs of plague on (A) Diploria labyrinthiformis and (B) Montastraea faveolata. (C) Plague and black band disease on Colpophyllia natans. All taken in St. Lucia 
Table 1. Mean percentage of plague-infected colonies for individual and pooled species within individual and pooled study sites. Significant differences between sites are indicated at the right-hand side. SE = standard error of the mean, $\mathrm{n}=$ total number of colonies

\begin{tabular}{|c|c|c|c|c|c|c|c|c|c|c|c|}
\hline & \multicolumn{2}{|c|}{ Turtle reef } & \multicolumn{2}{|c|}{ Anse Chastanet } & \multicolumn{2}{|c|}{ Grand Caille } & \multicolumn{2}{|c|}{ Pooled sites ${ }^{\mathrm{a}}$} & \multicolumn{3}{|c|}{ Significance $^{\mathrm{b}}$} \\
\hline & $x \pm \mathrm{SE}$ & $\mathrm{n}$ & $x \pm \mathrm{SE}$ & $\mathrm{n}$ & $x \pm \mathrm{SE}$ & $\mathrm{n}$ & $x \pm \mathrm{SE}$ & $\mathrm{n}$ & TR:AC & TR:GC & $\mathrm{AC}: \mathrm{GC}$ \\
\hline Colpophyllia natans & $15.4 \pm 1.1$ & 422 & $15.1 \pm 2.5$ & 425 & $8.6 \pm 1.3$ & 383 & $13.0 \pm 1.1$ & 1230 & ns & $*$ & $*$ \\
\hline Montastraea faveolata & $24.9 \pm 4.4$ & 272 & $21.4 \pm 3.5$ & 173 & $11.0 \pm 3.1$ & 151 & $19.1 \pm 2.4$ & 596 & ns & * & ns \\
\hline Montastraea annularis & $3.4 \pm 1.7$ & 196 & $3.4 \pm 1.4$ & 212 & $2.9 \pm 1.1$ & 165 & $3.2 \pm 0.8$ & 573 & ns & ns & ns \\
\hline Diploria labyrinthiformis & $2.5 \pm 1.4$ & 108 & $0.0 \pm 0.0$ & 75 & $7.8 \pm 3.6$ & 103 & $3.6 \pm 1.4$ & 286 & ns & ns & ns \\
\hline Diploria strigosa & $11.3 \pm 4.7^{\mathrm{c}}$ & 62 & $3.3 \pm 2.5^{\mathrm{c}}$ & 47 & $6.4 \pm 3.3$ & 75 & $7.2 \pm 2.1$ & 184 & ns & ns & ns \\
\hline Stephanocoenia michelinii & $6.6 \pm 2.6^{\mathrm{c}}$ & 57 & $11.0 \pm 4.8^{\mathrm{c}}$ & 30 & $4.0 \pm 2.4$ & 125 & $6.9 \pm 1.8$ & 212 & ns & ns & ns \\
\hline Pooled species ${ }^{\mathrm{d}}$ & $13.8 \pm 1.7$ & 1117 & $11.9 \pm 1.4$ & 962 & $7.1 \pm 0.9$ & 1002 & $11.0 \pm 0.9^{\mathrm{e}}$ & 3081 & ns & $*$ & $*$ \\
\hline
\end{tabular}

origin of the disease. Although rare, corals affected by both plague and black band disease have also been observed (Fig. 2C).

Besides the 6 species studied, other coral species affected by plague within the 27 transects were: Agaricia agaricites, Dichocoenia stokesii, Isophyllastrea rigida, Meandrina meandrites, Montastraea cavernosa, Mycetophyllia sp. and Siderastrea siderea. Cases of plague were also observed on Agaricia lamarcki, Dendrogyra cylindricus, Mussa angulosa and Manicina areolata at other areas on these reefs, making a minimum of 17 coral species infected by the disease.

\section{Abundance and distribution of diseased corals}

The 27 replicate transects on the 3 reefs covered $5400 \mathrm{~m}^{2}$ of reef, containing a total of 3081 colonies of the 6 species studied (Table 1). The incidence of infected colonies (species pooled) averaged $11.0 \%$ of the total number of colonies present, with a range of 3.7 to $25.0 \%$ per transect. The percent of infected colonies (species pooled) was significantly different among the 3 reefs (1-way ANOVA, $F_{2,24}=6.32, \mathrm{p}=$ 0.006). Grand Caille, with an average of $7.1 \%$ of infected colonies per transect, was significantly less affected than Turtle reef and Anse Chastanet, which averaged 13.8 and $11.9 \%$ infected colonies per transect respectively (SNK, $\mathrm{p}<0.05$, Table 1 ).

There were significant differences among species (sites pooled) in the rate of infection (Kruskal-Wallis test, $H=50.7$, df $=5, p<0.0001$ ). A Dunn's multiple comparison test showed that Montastraea faveolata and Colpophyllia natans were significantly more infected than any of the other species studied $(\mathrm{p}<0.05)$. Overall disease incidence was $19.1 \%$ with a maximum of $24.9 \%$ at Turtle reef in $M$. faveolata, and $13.0 \%$ with a maximum of $15.4 \%$ also at Turtle reef in C. natans (Table 1).

The percent of infected colonies among individual or pooled species was not significantly correlated with colony density (count per $200 \mathrm{~m}^{2}$ transect) (Spearman's rank-correlation, $\mathrm{n}=27, \mathrm{p}>0.05)$. Further, the frequency distribution of $5 \times 5 \mathrm{~m}$ plots with various levels of infections among pooled species did not differ significantly from a Poisson distribution (Fig. 3), suggesting that the distribution of infected colonies was not clumped on a $5 \times 5 \mathrm{~m}$ scale.

\section{Influence of colony size}

The mean surface area of infected colonies was significantly greater than the mean surface area of colonies in the overall population (Table 2, Fig. 4). This difference was consistent among reefs and species (no significant interaction between reef and disease status, and between species and disease status in Table 2). This suggests that large colonies have a greater probability of infection by plague compared to small colonies within a particular species. Unfortunately, the sampling design did not allow me to test for variations among species while controlling for the effect of colony size. Montastraea faveolata, which was significantly larger than Colpophyllia natans (Table 2, Fig. 4), had a greater disease incidence than $C$. natans (Table 1 ). However $M$. annularis, which was similar in size to $M$. faveolata at the studied sites (pers. obs.), had the lowest disease incidence of the 6 species studied (Table 1). Therefore, colony size is unlikely to be the only factor influencing differences in disease incidence among species. 


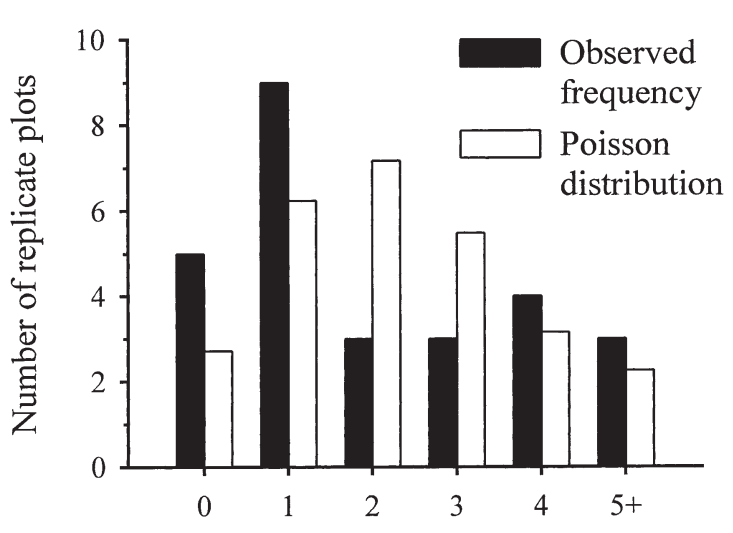

Number of infected colonies per plot

Fig. 3. Frequency distribution of the numbers of $5 \times 5 \mathrm{~m}$ plots ( $\mathrm{n}=27$ ) with 0 to 5 or more infected coral colonies (species pooled) together with the corresponding Poisson distribution (Sokal \& Rohlf 1995). If the numbers of infected colonies per replicate plot occur independently of each other, they will follow the Poisson distribution. Here there was no significant difference between the frequency distribution and the Poisson distribution ( $G$-test, $G_{\text {adj }}=7.11, \mathrm{df}=4, \mathrm{p}=0.13$ ). This indicates that the occurrence of a diseased colony did not enhance the probability of finding a second one in the same plot, suggesting that infection rates were unaffected by proximity to other diseased colonies

Tissue mortality from disease (percentage of colony surface area killed) decreased logarithmically with colony surface area (sites and species pooled, Table 3 , Fig. 5A). This relationship did not differ among species $\left(F_{8,359}=1.06, \mathrm{p}=0.39\right.$ for the interaction between the $\log _{\mathrm{e}}$ of colony surface area and species). Put together, these data suggest that, although large colonies have a greater probability of infection compared to small colonies, they lose less living tissue relative to their size. Therefore, large colonies are less likely to suffer complete colony death from the disease.

Tissue mortality was highest in species with colonies having a small mean size (Fig. 5B). However, when the

Table 2. Results of 3-way ANOVA with the $\log _{\mathrm{e}}$ of colony surface area as dependent variable and species (Colpophyllia natans vs Montastraea faveolata), disease status (infected colonies vs all colonies) and reef (Turtle reef vs Grand Caille) as independent variables

\begin{tabular}{|lrrrrc|}
\hline Source & SS & df & MS & $F$ & $p$ \\
\hline Species & 26.73 & 1 & 26.73 & 11.60 & 0.001 \\
Status & 52.27 & 1 & 52.27 & 22.68 & 0.000 \\
Reef & 4.46 & 1 & 4.46 & 1.93 & 0.165 \\
Species $\times$ Status & 0.43 & 1 & 0.43 & 0.19 & 0.666 \\
Species $\times$ Reef & 2.59 & 1 & 2.59 & 1.12 & 0.290 \\
Status $\times$ Reef & 1.60 & 1 & 1.60 & 0.69 & 0.405 \\
Species $\times$ Status $\times$ Reef & 0.36 & 1 & 0.36 & 0.16 & 0.694 \\
Error & 1064.67 & 462 & 2.30 & & \\
Total & 1204.42 & 469 & & & \\
\hline
\end{tabular}

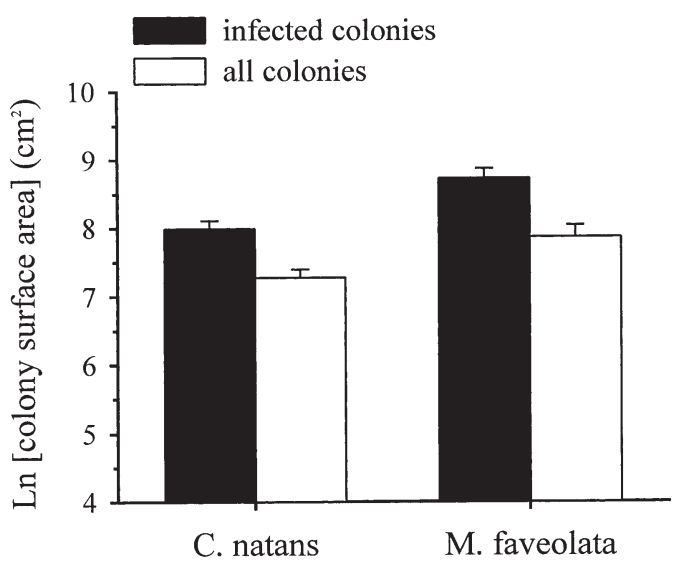

Fig. 4. Mean colony surface area $( \pm \mathrm{SE})$ of infected colonies and of all colonies (sites pooled) for Colpophyllia natans and Montastraea faveolata. Total numbers of colonies surveyed at Turtle reef and Grand Caille were: C. natans: infected colonies 65, 33, all colonies 153, 40; M. faveolata: infected colonies 67,17 , all colonies 74, 21

effect of differences in size among species was accounted for, there still remained significant differences among species in tissue mortality within infected colonies (Table 3). Infected Montastraea annularis colonies had significantly less tissue mortality per average size colony $\left(2921 \mathrm{~cm}^{2}\right)$ than Mycetophyllia sp., Dichocoenia stockesii, Meandrina meandrites and Montastraea faveolata (pairwise comparisons in Table 3).

\section{Loss in living coral cover after 8 months of plague outbreak}

In March 1998, overall coral tissue loss per $100 \mathrm{~m}^{2}$ of reef area (sites pooled) was $1.5 \mathrm{~m}^{2}( \pm 0.3 \mathrm{SE}$ ) and represented a loss of $3.1 \%$ of living coral cover estimated in July 1997 (Table 4). Turtle reef was the most damaged reef with a loss of $6.6 \%$ of coral cover and $8.1 \%$ of the cover of the massive species. At any given reef, loss of tissue from colonies of Montastraea faveolata and Colpophyllia natans together constituted more than $90 \%$ of the estimated loss in living coral cover (Table 4).

\section{Short-term impact of plague on infected colonies}

Tissue mortality in the 64 marked colonies infected by plague in February 1998 significantly increased between February and October 1998 (Table 5, Fig. 6A). The rate of increase 
Table 3. ANCOVA results with tissue mortality (i.e. \% colony surface area killed by the disease) as dependent variable, species as independent variable and the $\log _{\mathrm{e}}$ of colony surface area as covariate. Pairwise comparisons between species' means adjusted to an average colony size of $2921 \mathrm{~cm}^{2} .{ }^{*} \mathrm{p}<0.05, \mathrm{~ns}=$ not significant

\begin{tabular}{|c|c|c|c|c|c|c|c|c|c|}
\hline Source & & SS & df & MS & \multicolumn{2}{|c|}{$F$} & \multicolumn{3}{|l|}{$\mathrm{p}$} \\
\hline Species & & 25972.21 & 8 & 3246.12 & \multicolumn{2}{|c|}{22.79} & \multicolumn{3}{|l|}{0.000} \\
\hline Colony size & & 11259.09 & 1 & 11259.1 & \multicolumn{2}{|c|}{95.38} & \multicolumn{3}{|l|}{0.000} \\
\hline Error & & 181342.03 & 367 & 494.12 & & & & & \\
\hline Total & & 227701.08 & 376 & & & & & & \\
\hline \multicolumn{10}{|c|}{ Pairwise comparisons and adjusted means $\mathrm{s}^{\mathrm{a}}$} \\
\hline & Myce & Dsto & Mmea & Mfav & Dstr & Dlab & Cnat & Smic & Mann \\
\hline Myce & 54.0 & ns & ns & ns & ns & ns & ns & $\mathrm{ns}$ & * \\
\hline Dsto & & 51.4 & ns & ns & ns & ns & ns & ns & * \\
\hline Mmea & & & 39.5 & ns & ns & ns & ns & $\mathrm{ns}$ & * \\
\hline Mfav & & & & 35.8 & ns & ns & $*$ & ns & * \\
\hline Dstr & & & & & 26.4 & ns & ns & $\mathrm{ns}$ & ns \\
\hline Dlab & & & & & & 26.3 & ns & $\mathrm{ns}$ & ns \\
\hline Cnat & & & & & & & 23.8 & ns & ns \\
\hline Smic & & & & & & & & 22.7 & ns \\
\hline Mann & & & & & & & & & 11.6 \\
\hline \multicolumn{10}{|c|}{${ }^{a}$ Adjustment for multiple comparisons: Bonferroni } \\
\hline \multicolumn{10}{|c|}{$\begin{array}{l}\text { Myce = Mycetophyllia sp., Dsto = Dichocoenia stokesii, Mmea = Meandrina meandrites, Mfav = Montastraea faveolata } \\
\text { Dstr = Diploria strigosa, Dlab = Diploria labyrinthiformis, Cnat = Colpophyllia natans, Smic = Stephanocoenia michelinii } \\
\text { Mann = Montastraea annularis }\end{array}$} \\
\hline
\end{tabular}
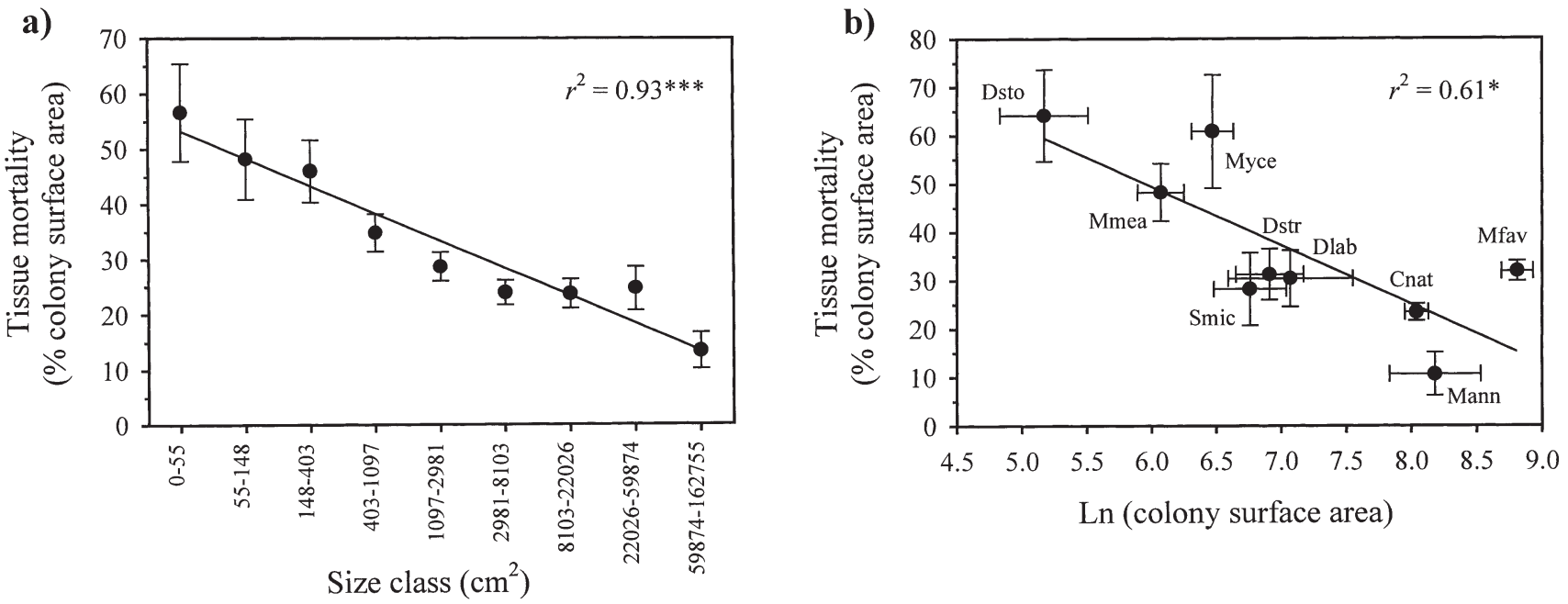

Fig. 5. Tissue mortality (\% colony surface area killed by the disease). (A) Means ( \pm SE, $n=3$ to 93) for each size class (sites and species pooled). (B) Mean percent tissue loss ( $\pm \mathrm{SE}, \mathrm{n}=6$ to 167 ) versus mean colony surface area $\left(\mathrm{cm}^{2}\right)$ for each species. Species abbreviation indicated next to each mean. For full names see Table $3 .{ }^{*} p<0.05,{ }^{* *} p<0.001$

was similar among species and reefs (no significant interaction terms in Table 5). In February 1998, tissue mortality for Colpophyllia natans and Montastraea faveolata averaged 32.8 and $35.9 \%$ respectively. Eight months later, it increased to 55.7 and $50.5 \%$ respectively (Fig. 6A). Two colonies (having surface areas of $\sim 1$ and $\sim 0.3 \mathrm{~m}^{2}$ respectively) were completely dead in October 1998.
Measurements of the rate of progression of the disease front indicated no tissue regrowth in any of the 64 colonies. Disease fronts moved horizontally an average of $7.6 \mathrm{~cm}$ per colony $( \pm 0.9 \mathrm{SE}, \mathrm{n}=61)$, with a range of 0.0 to $30.8 \mathrm{~cm}$ per colony. This is equivalent to an average of $0.3 \mathrm{~mm} \mathrm{~d}^{-1}$, with a maximum of $1.3 \mathrm{~mm} \mathrm{~d}^{-1}$ over the 8 mo period. Only 8 colonies $(12.5 \%)$ showed no or little change in the disease 
Table 4. Mean surface loss of living coral as a result of plague for individual and pooled sites estimated in March 1998 (n = 9 transects per site), mean surface area of living coral estimated in July 1997 (data from Roberts et al. 1997, n = 12 to 13 quadrats per site), and estimated percent of tissue killed by the disease. SEM = standard error of the mean

\begin{tabular}{|c|c|c|c|c|}
\hline & $\begin{array}{c}\text { Turtle reef } \\
x \pm \text { SEM }\end{array}$ & $\begin{array}{c}\text { Anse Chastanet } \\
x \pm \text { SEM }\end{array}$ & $\begin{array}{c}\text { Grand Caille } \\
x \pm \text { SEM }\end{array}$ & $\begin{array}{c}\text { Pooled sites }^{\mathrm{a}} \\
x \pm \text { SEM }\end{array}$ \\
\hline \multicolumn{5}{|c|}{ Surface loss of living coral due to plague $\left(\mathrm{m}^{2} 100 \mathrm{~m}^{-2}\right)$} \\
\hline Pooled species & $2.7 \pm 0.5$ & $1.3 \pm 0.3$ & $0.6 \pm 0.1$ & $1.5 \pm 0.3$ \\
\hline Colpophyllia natans & $0.3 \pm 0.1$ & $0.7 \pm 0.2$ & $0.3 \pm 0.1$ & $0.4 \pm 0.1$ \\
\hline Montastraea faveolata & $2.3 \pm 0.5$ & $0.6 \pm 0.2$ & $0.2 \pm 0.1$ & $1.0 \pm 0.2$ \\
\hline \multicolumn{5}{|c|}{ Surface of living coral $\left(\mathrm{m}^{2} 100 \mathrm{~m}^{-2}\right)$} \\
\hline Pooled species & $41.5 \pm 6.1$ & $60.0 \pm 6.4$ & $47.0 \pm 4.8$ & $49.6 \pm 3.5$ \\
\hline Massive coral species only & $33.7 \pm 6.3$ & $52.0 \pm 7.0$ & $33.7 \pm 5.7$ & $40.0 \pm 3.9$ \\
\hline \multicolumn{5}{|c|}{ Minimum estimated \% tissue killed by WPD } \\
\hline Pooled species & 6.6 & 2.2 & 1.2 & 3.1 \\
\hline Massive coral species only & 8.1 & 2.5 & 1.7 & 3.9 \\
\hline
\end{tabular}

Table 5. Repeated measures ANOVA of tissue mortality (i.e. \% colony surface area killed by the disease) in tagged colonies with species (Colpophyllia natans vs Montastraea faveolata) and reef (Turtle reef vs Anse Chastanet) as betweenfactor variables and time (February 1998 vs October 1998) as within-factor variables

\begin{tabular}{|lrrrrc|}
\hline $\begin{array}{l}\text { Tests of between-subjects effects: } \\
\text { Source }\end{array}$ & SS & df & MS & $F$ & $\mathrm{p}$ \\
\hline Species & 29.90 & 1 & 29.90 & 0.03 & 0.859 \\
Reef & 2191.44 & 1 & 2191.44 & 2.33 & 0.132 \\
Species $\times$ Reef & 204.90 & 1 & 204.90 & 0.22 & 0.642 \\
Error & 56349.76 & 60 & 939.16 & & \\
Tests of within-subjects contrasts: & & & & \\
Source & SS & df & MS & $F$ & p \\
\hline Time & & & & & \\
Time $\times$ Reef & 9067.41 & 1 & 9067.41 & 66.27 & 0.000 \\
Time $\times$ Species & 58.03 & 1 & 58.03 & 0.42 & 0.517 \\
Time $\times$ Reef $\times$ Species & 444.03 & 1 & 444.03 & 3.25 & 0.077 \\
Error & 100.28 & 1 & 100.28 & 0.73 & 0.395 \\
& 8209.66 & 60 & 136.83 & & \\
\hline
\end{tabular}

front $(<1 \mathrm{~cm}$ loss) (Fig. $6 \mathrm{~B})$ but $32.8 \%$ of the colonies had tissue loss exceeding $10 \mathrm{~cm}$ (Fig. 6B). There was no significant difference in the rate of progression of disease fronts among species or reefs (2-way ANOVA with species and reef, $F_{1,57}=2.08, \mathrm{p}=0.16$ and $F_{1,57}=0.02, \mathrm{p}=0.89$ for species and reef respectively).

Eighteen out of the 64 colonies (28.1\%) still showed signs of plague in October 1998. Note that these colonies did not suffer greater tissue mortality compared to the other colonies (repeated measures ANOVA on tissue mortality with disease status in October 1998 as between-factor variable and time as within-factor variable, $F_{1,62}=0.02, \mathrm{p}=0.89$ for the interaction between disease status and time).

No new coral recruit was observed on the substrate opened up by the disease within the close-up photographs. Instead, algal turfs were the major space colonisers. Macroalgae covered an average of $23.0 \%$ $( \pm 3.0 \mathrm{SE}, \mathrm{n}=64)$ of the newly exposed skeletons in October 1998. Progression of the disease front was also surveyed over the same period in 3 infected colonies of Montastraea annularis. None showed tissue regrowth but their disease fronts only moved to an average of $0.3,0.4$ and $1.7 \mathrm{~cm}$ over the 8 mo period. Further, none of the 3 colonies showed any sign of disease in October 1998.

\section{DISCUSSION}

\section{Abundance and distribution of diseased colonies}

Comparison of these results and the 2 previous quantitative studies on plague in the Florida Keys in 1995 (Richardson et al. 1998a) and in Puerto Rico in 1996 (Bruckner \& Bruckner 1997) confirm that plague can affect a large number of coral species and a large percentage of colonies within some species. In the Florida Keys outbreak of 1995, 17 coral species were observed infected by plague; Dichocoenia stokesii was the most affected species with a disease incidence of $20.1 \%$ (range of 0.0 to $33.3 \%$ site $^{-1}$ ) in June 1995. On 

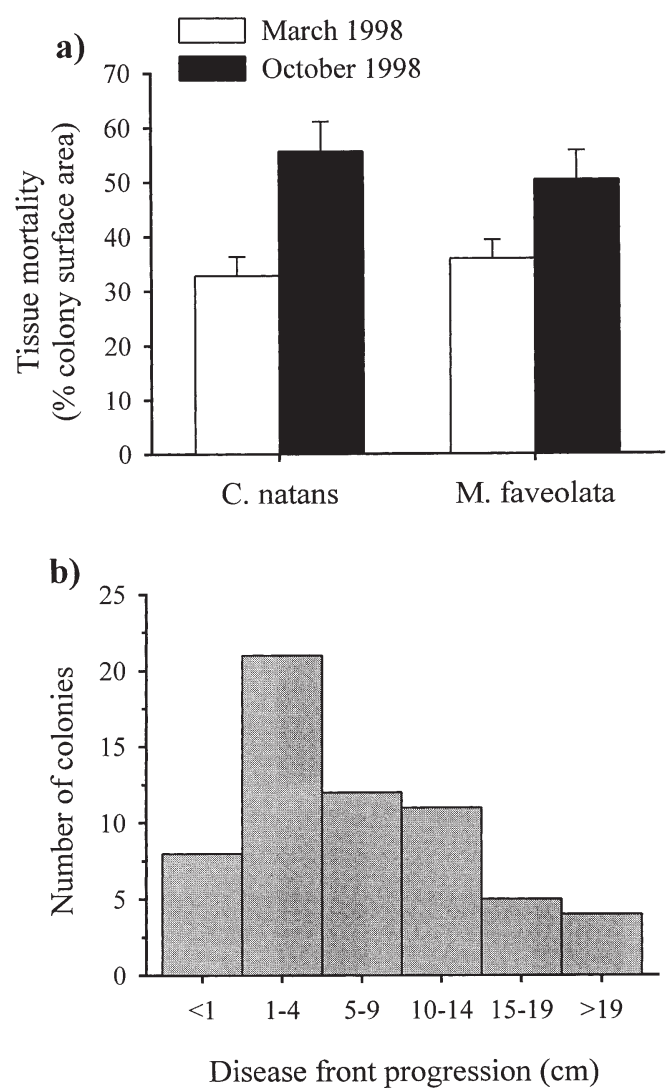

Fig. 6. (A) Tissue mortality (\% colony surface area killed by the disease). Means ( $\pm \mathrm{SE}, \mathrm{n}=32$ ) in February 1998 and October 1998 for Colpophyllia natans and Montastraea faveolata (sites pooled). (B) Frequency distribution of the distance disease fronts progressed on infected colonies between February 1998 and October 1998 (sites and species pooled). $\mathrm{n}=61$

Mario Reef in Puerto Rico, plague spread among 5 coral genera and was most severe on Diploria labyrinthiformis with $47 \%$ of colonies infected within a $100 \mathrm{~m}^{2}$ of reef area between August and December 1996.

A major difference between this study and the 2 previous studies is in the identity of the coral species most affected by the disease. In this study, neither Diploria labyrinthiformis nor Dichocoenia stokesii were the most affected species. Disease incidence for D. labyrinthiformis was $3.6 \%$ (with a range of 0.0 to $7.8 \%$ site $^{-1}$ ) and only 6 colonies of $D$. stokesii were infected by plague within $5400 \mathrm{~m}^{2}$ of reef area. Instead, the disease targeted 2 spatially dominant coral species with large mean colony size. Montastraea faveolata and Colpophyllia natans together commonly accounted for between 30 and $60 \%$ of the coral cover in the study area (unpubl. data). Additionally, the distribution of diseased colonies on a $5 \times 5 \mathrm{~m}$ scale was found to be random and disease frequency was not density dependent. This differs from the clumped distribution (in
$20 \mathrm{~m}$ diameter plots) reported by Richardson et al. (1998a). More research should investigate the mechanisms of disease transmission and whether these differences could be associated with differences in pathogens, environmental conditions and/or coral community composition (Richardson et al. 1998b).

\section{Effects on coral population structure}

Results suggest that small coral colonies are more likely to escape infections than large ones, but when infection occurs, small colonies suffer greater tissue loss relative to their size. Similar trends have been found in other studies with regard to partial mortality (e.g. Hughes \& Jackson 1980, 1985, Rylaardsam 1983, Babcock 1991, Meesters et al. 1997). Supposing that the disease agent spreads randomly on an areal basis, a small colony will have a low probability of infection. However, once infected, if the rate of tissue destruction is assumed to be constant irrespectively of the size of the colony, then a small colony will experience mortality faster than a large colony. Consequently, I predict that the effect of plague on coral population structure will be greater total mortality in small colonies relative to large colonies, at least over short-time scales. Similar predictions have been made with regard to global change by Bak \& Meesters (1999).

Species still differed in rates of tissue mortality when colony surface area was standardised. Particularly, Montastraea annularis had the lowest disease incidence and colony tissue mortality although it is among the largest coral species. While some of these differences might be due to specific disease resistance capabilities, species morphology may play an important role. In the case of $M$. annularis, this species grows in columns. Generally, only the top parts of the columns are covered with living tissue (Weil \& Knowlton 1994). Hence, the separation and autonomy of colony lobes may slow down or reduce the chance of infection to spread over the entire colony. More research is required to understand the role of species morphology on disease susceptibility.

\section{Importance of plague and prospects for recovery}

Eight months after the start of the outbreak, plague was estimated to have killed $6.6 \%$ of living coral tissue at the most severely affected site (Turtle reef). This number may appear insignificant when compared to other major disturbances affecting coral reefs. For example, sediment deposition following Tropical Storm Debbie caused over $50 \%$ coral mortality at some sites in St. Lucia in 1994 (Sladek Nowlis et al. 1997). How- 
ever, this study shows that the impacts of plague differ from these disturbances in: (1) its selective destruction of 2 important reef frame builders; and (2) its persistent impact on infected colonies.

Firstly, Montastraea faveolata and Colpophyllia natans together made up more than $90 \%$ of the estimated tissue loss. The impact of plague on these species is of major concern for the maintenance of the reef framework since they are the most important reef frame builders in the study area. These species are long-lived, slow-growing and have low recruitment rates. Their competitive ability over fast-growing, high recruitment species depends particularly on their resistance to damage and natural disturbances (Bak \& Engel 1979). Hence for such species, small increases in mortality rate may be serious. In addition, the partial mortality induced by the disease may have further detrimental effects on competitive abilities, growth, reproduction and resistance of the diseased colonies to injuries and to other diseases. For example, regeneration of lesions has been found to affect colony growth (Bak 1983, Meesters et al. 1994) and reproduction (Rinkevich \& Loya 1989, Van Veghel \& Bak 1994). Szmant-Froelich (1985) found that large colonies had higher reproductive success than small.

Secondly, none of the 64 infected colonies surveyed in this study showed any regrowth of tissue killed by the disease from February 1998 to October 1998, and $28 \%$ still showed signs of disease in October 1998. No new coral recruits were observed on the substrate opened up by the disease during the same period. When living coral was lost, it was replaced by substrates dominated by turf algae and macroalgae. Although the methodology of this study did not allow me to establish whether the disease was directly responsible for the subsequent loss of tissue from the infected colonies and the low rates of coral recruitment, together these observations suggest a persistent impact of the disease on infected colonies in the study area. Bruckner \& Bruckner (1997) observed that plague may reappear on the same colony every year during warm water months until complete colony death in Puerto Rico. Continuous loss of tissue has also been observed after infections had stopped on small surviving patches of tissue in the Florida Keys by Dustan (1977) and on colonies previously infected by black band disease, also in the Florida Keys, by Kuta \& Richardson (1997).

In conclusion, although the regional effects of plague are not as striking as those inflicted by other disturbances, this study suggests that they may cause more persistent changes to local population and community structure. While small colonies appear worst affected, if the loss of tissue continues on large infected colonies, plague may also cause complete mortality in large colonies. Since this survey was undertaken, diseased colonies have been observed on other reefs south of the 3 study sites from July to August 1999 and 2000 (Callum Roberts pers. comm.). Ultimately, if losses are sustained at such rates, plague may progressively eliminate 2 of the main Caribbean reef builders in some of the most species rich and most visited coral reefs of St. Lucia.

Acknowledgements. This research was funded by grants from the UK Darwin Initiative and NERC secured by Callum Roberts. Thanks are due to the St. Lucia Department of Fisheries and Soufrière Marine Management Area for their support for the project, with special thanks to Horace Walters, Dawn Pierre and Suzanna Scott of the Department of Fisheries, and Kai Wulf and the wardens of the Soufrière Marine Management Area. I am very grateful to Roger Malone, Ronnie Nicholas, Douane Joseph and Daniel Nugues for field assistance. Michael and Karyn Allard and Scuba St. Lucia generously provided diving facilities for which I am greatly indebted. I thank Callum Roberts, Erich Mueller, Bruce Hatcher and 3 anonymous reviewers for their comments on the manuscript.

\section{LITERATURE CITED}

Antonius A (1973) New observations on coral destruction in reefs. Tenth Meeting of the Association of Island Marine Laboratories of the Caribbean 10:3 (Abstracts)

Antonius A (1977) Coral mortality on reefs: a problem for science and management. Proc 3rd Int Coral Reef Symp 2: $618-623$

Aronson RB, Precht WF (1997) Stasis, biological disturbance, and community structure of a Holocene coral reef. Paleobiology 23:326-346

Babcock RC (1991) Comparative demography of three species of scleractinian corals using age- and size-dependent classifications. Ecol Monogr 61:225-244

Bak RPM (1983) Neoplasia, regeneration and growth in the reef-building coral Acropora palmata. Mar Biol 77:221-227

Bak RPM, Engel MS (1979) Distribution, abundance and survival of juvenile hermatypic corals (Scleractinia) and the importance of life history strategies in the parent coral community. Mar Biol 54:341-352

Bak RPM, Meesters EH (1998) Coral population structure: the hidden information of colony size-frequency distributions. Mar Ecol Prog Ser 162:301-306

Bak RPM, Meesters EH (1999) Population structure as a response of coral communities to global change. Am Zool 39:56-65

Bruckner AW, Bruckner RJ (1997) Outbreak of coral disease in Puerto Rico. Coral Reefs 16:260

Coles SL (1994) Extensive coral disease outbreak at Fahl Island, Gulf of Oman, Indian Ocean. Coral Reefs 13:242

Dustan P (1977) Vitality of reef coral populations off Key Largo, Florida: Recruitment and mortality. Environ Geol 2: $51-58$

Dustan P, Halas JC (1987) Changes in the reef-coral community of Carysfort Reef, Key Largo, Florida: 1974 to 1982. Coral Reefs 6:91-106

Edmunds PJ (1991) Extent and effect of black band disease on a Caribbean reef. Coral Reefs 10:161-165

Garrett P, Ducklow H (1975) Coral diseases in Bermuda. Nature 253: 349-350 
Goreau TJ, Cervino J, Goreau M, Hayes R and 14 others (1998) Rapid spread of diseases in Caribbean coral reefs. Rev Biol Trop (Suppl 46) 5:157-171

Harvell CD, Kim K, Burkholder JM, Colwell RR and 9 others (1999) Emerging marine diseases - climate links and anthropogenic factors. Science 285:1505-1510

Hughes TP, Jackson JBC (1980) Do corals lie about their age? Some demographic consequences of partial mortality, fission, and fusion. Science 209:713-715

Hughes TP, Jackson JBC (1985) Population dynamics and life histories of folacious corals. Ecol Monogr 55:141-166

Kuta KG, Richardson LL (1996) Abundance and distribution of black band disease on coral reefs in the northern Florida Keys. Coral Reefs 15:219-223

Kuta KG, Richardson LL (1997) Black band disease and the fate of diseased coral colonies in the Florida Keys. Proc 8th Int Coral Reef Symp 1:575-578

Meesters EH, Noordeloos M, Bak RPM (1994) Damage and regeneration: links to growth in the reef-building coral Montastrea annularis. Mar Ecol Prog Ser 112:119-128

Meesters EH, Wesseling I, Bak RPM (1997) Coral colony tissue damage in six species of reef-building corals: partial mortality in relation to depth and surface area. J Sea Res 37:131-144

Miller I (1996) Black band disease on the Great Barrier Reef. Coral Reefs 15:58

Peters EC (1993) Diseases of other invertebrate phyla: Porifera, Cnidaria, Ctenophora, Annelida, Echinodermata. In: Couch JA, Fournie JW (eds) Pathobiology of marine and estuarine organisms. CRC Press, Boca Raton, FL, p 393-449

Peters EC (1996) Diseases of coral-reef organisms. In: Birkeland C (ed) Life and death of coral reef. Chapman and Hall, New York, p 114-139

Precht WF, Aronson RB (1997) White band disease in the Florida Keys - a continuing concern. Reef Encounter 22: 14-16

Richardson LL (1998) Coral diseases: what is really known? TREE 13:438-443

Richardson LL, Goldberg WM, Kuta KG, Aronson RB, and 5 others (1998a) Florida's mystery coral-killer identified.

Editorial responsibility: Rolf Bak (Contributing Editor),

Den Burg, Texel, The Netherlands
Scientific correspondence. Nature 392:557-558

Richardson LL, Goldberg WM, Carlton RG, Halas JC (1998b) Coral disease outbreak in the Florida Keys: plague type II. Rev Biol Trop (Suppl 46) 5:187-198

Rinkevich B, Loya Y (1989) Reproduction in regenerating colonies of the coral Stylophora pilstillata. In: Spanier E, Steinberger Y, Luria M (eds) Environmental quality and ecosystem stability. Hebrew University, Jerusalem, p 257-265

Roberts CM (1993) Coral reefs: health, hazards and history. TREE 8:425-427

Roberts CM, Hawkins JP (1997) How small can a marine reserve be and still be effective? Coral Reefs 16:150

Roberts CM, Nugues MM, Hawkins J (1997) Report on the 1997 survey of coral reefs of the Soufrière Marine Management Area and Anse La Raye, St. Lucia. Environment Department, University of York, p 51

Rylaarsdam KW (1983) Life histories and abundance patterns of colonial corals on Jamaican reefs. Mar Ecol Prog Ser 13: 249-260

Santavy DL, Peters EC (1997) Microbial pests: Coral disease in the western Atlantic. Proc 8th Int Coral Reef Symp 1: $607-612$

Sladek Nowlis J, Roberts CM, Smith AH, Siirila E (1997) Human-enhanced impacts of a tropical storm on nearshore coral reefs. Ambio 26:515-521

Sokal RR, Rohlf FJ (1995) Biometry, 3rd edn. Freeman, New York

Szmant-Froelich A (1985) The effect of colony size on the reproductive ability of the Caribbean coral Montastrea annularis (Ellis and Solander). Proc 5th Int Coral Reef Symp 4:295-300

Van Veghel MLJ, Bak RPM (1994) Reproductive characteristics of the polymorphic Caribbean reef building coral Montastrea annularis. III. Reproduction in damaged and regenerating colonies. Mar Ecol Prog Ser 109:229-233

Weil E, Knowlton N (1994) A multi-character analysis of the Caribbean coral Montastraea annularis (Ellis and Solander, 1786) and its two sibling species, M. faveolata (Ellis and Solander, 1786) and M. franksi (Gregory, 1895). Bull Mar Sci 55:151-175

Submitted: May 15, 2000; Accepted: August 28, 2001

Proofs received from author(s): February 20, 2002 